\title{
OCCUPATIONAL Noise ANd BLOOd PRESSURE VARIATION
}

\author{
P. Nassiri ${ }^{* 1}$, A.M. Abbasi ${ }^{2}$, A.H. Poornadjaf ${ }^{2}$, P. Jafari Shalkouhi ${ }^{3}$, P. Bahrami ${ }^{1}$ \\ ${ }^{1}$ Department of Occupational Health Engineering, The School of Public Health, Tehran \\ University of Medical Sciences, P.O Box 6446-14155, Tehran, Iran. \\ ${ }^{2}$ Ilam University of Medical Sciences, Ilam, Iran. \\ ${ }^{3}$ Department of Environmental Engineering, Faculty of Natural Resources and \\ Environment, Science and Research Branch, Islamic Azad University, Tehran, Iran. \\ *Corresponding author: P. Nassiri \\ nassiri@sina.tums.ac.ir
}

(Received October 2017- Accepted March 2019)

\begin{abstract}
P. Nassiri, A.M. Abbasi, A.H. Poornadjaf, P. Jafari Shalkouhi, P. Bahramia. 2019. Occupational noise and blood pressure variation. Lebanese Science Journal. 20(1): 148-160.

Previous studies have demonstrated association between exposure to occupational (workplace) noise and blood pressure. The goal of the present research was to investigate a relationship between noise exposure and blood pressure among 1374 workers from 12 companies. Based on a confidence level of 95\% ( $\alpha=0.05$ ), 175 workers as a case group and 174 as a control group were randomly selected. In addition, the participants were divided into different age and work experience groups. The results revealed that noise levels in most of companies exceeded the NIOSH (1998) standard. They also show a significant statistical relationship between exposures to occupational noise level $\geq 100 d B A$ (A-weighted decibel), hypertension and work experience $\geq 4$ years. It was concluded that to study an association between exposure to workplace noise and blood pressure, length of time on job must be taken into consideration.
\end{abstract}

Keywords: Hypertension, workers, companies, Iran.

http://dx.doi.org/10.22453/LSJ-020.1.148-160 National Council for Scientific Research - Lebanon 2018ㅇ lsj.cnrs.edu.lb/vol-20-no-1-2019/ 


\section{INTRODUCTION}

Noise pollution is a hazardous factor due to its gradual spread not only in workplaces but also in residential areas and inside buildings (Sancini et al., 2014). Occupational noise is the noise found in workplaces (Vincoli, 2000). Equipment, machinery and work practices are typically the sources of excessive noise in workplaces (Autenrieth, 2011; Jain et al., 2012). Noise affects both workers in workplaces and the neighborhoods around them. Therefore, it is necessary to consider both the internal and external aspects of workplace noise (Bugliarello et al., 1976).

According to OSHA (Occupational Safety and Health Administration), 8 hours exposure to occupational noise should not exceed $90 \mathrm{dBA}$. While, according to NIOSH (National Institute of Occupational Safety and Health) and ACGIH (American Conference of Governmental Industrial Hygienists), 8 hours exposure to workplace noise should not surpass $85 \mathrm{dBA}$ (Green, 2014).

Noise frequency, intensity, exposure duration and intermittence or continuation can interfere with our activity at three levels: (1) auditory effects which can interfere with satisfactory performance of hearing mechanism, (2) non-auditory effects which can interfere with social behavior of subjects, and (3) physiological effects which can interfere with biological function of body (Agarwal, 2009).

Chronic exposure to noise is associated with increased risk of high blood pressure (hypertension) (Lafferty, 2013). On the other hand, work in jobs with high demand and low decision latitude has been associated with hypertension (Levy et al., 2005). Hypertension is called the silent disease or silent killer because there is no clear warning sign to an individual that he or she might have high blood pressure (Krueger et al., 2007). Also, hypertension exerts excessive strain on cardiovascular system, including heart, arteries, brain and kidneys (Aziz and Aziz, 2015).

Nassiri and Abbasi (2009) reported a relationship between exposure to noise and blood pressure in textile industry. Fogari et al. (1994) investigated an association of noise exposure with blood pressure in a metallurgical company. They concluded that occupational exposure to noise may increase a risk of hypertension. Ismaila and Odusote (2014) results revealed a relationship between exposure to noise and blood pressure among workers of a sack manufacturing company. Chen et al. (2015) studied blood pressure status among workers of a semiconductor manufacturing plant. They concluded that occupational exposure to noise can cause a significant rise in blood pressure. Zamanian et als (2013) results showed that noise exposure had no influence on blood pressure of workers of a steel company. Stokholm et al. (2013) found no link between noise exposure and hypertension among workers from 625 companies.

Most of existing studies analyzed the topic in specific companies where a narrow range of occupational noise levels existed. Whereas for each $5 \mathrm{~dB}$ increase in 
occupational noise exposure there is an increase of $0.51 \mathrm{~mm} \mathrm{Hg}$ in systolic blood pressure and a 1.14 relative risk of hypertension (van Kempen et al., 2002), the present study aims to analyze the topic in 12 different companies to cover a wide range of occupational noise levels. Moreover, age is a foremost risk factor for developing high blood pressure (Loue and Sajatovic, 2012). Also, whereas chronic exposure to noise is associated with increased risk of hypertension (Lafferty, 2013); work experience can be also associated with increased risk of hypertension too. Hence, the present study considers age and work experience to investigate an association between exposure to noise and hypertension among workers.

\section{MATERIAL AND METHODS}

A quantitative study was conducted (during the period of Jul-Dec 2016) to investigate a relationship between exposure to noise and blood pressure among workers from 12 industries including syringe, chemical materials, biscuit, gas, petrochemical materials, fertilizer, gunny, buffer, meat, flour, cement and cloth. Meanwhile, all companies were located in Ilam city situated in the west of Iran.

In general quantitative research is based on data which can be described as numeric, statistic and analytic data. Examples are all kinds of statistics, surveys, timescales etc. (Ernst, 2003).

Confounding factors which can affect blood pressure were controlled during the study. It means that, smoker workers and workers who had cardiovascular disease, headache, vertigo, abnormal blood cholesterol, tachycardia, abnormal blood sugar and kidney disorder, were removed from the survey. Also, all workers had proper eating habits with regard to blood pressure and none of them used hearing protection devices (HPDs).

Although other confounding factors including cold work environment, work stress, physical demand, hot and humid work environment can affect blood pressure (OSHB, 2008), all those factors were normal during the survey.

To investigate a relationship between noise exposure and blood pressure among 1374 male workers from 12 companies, 175 workers as a case group and 174 as a control group were randomly selected based on a confidence level of 95\% ( $\alpha=0.05)$. Workers in the control group were exposed to noise level below $75 \mathrm{dBA}$, while most of workers in the case group were exposed to noise level higher than $85 \mathrm{dBA}$.

To know whether 8 hours exposure to workplace noise can cause hypertension, blood pressure of the participants was measured after a work shift (8am-4pm) using conventional monometers. First, the subjects were examined by physicians. Second, systolic and diastolic blood pressure of them was measured 3 times at 5 minute intervals when they were in a lying position for 15-20 minutes. Finally, the mean of the 3 
measurements was calculated (WHO-ISH, 1999). Meanwhile, none of the subjects had white coat syndrome.

To measure workplace noise level, a Brüel \& Kjær sound level meter model 2230 was used. This is an instrument that measures SPL (Sound Pressure Level), Leq (Equivalent Sound Level) and SEL (Sound Exposure Level) in two measurement modes (Peak and RMS (Root Mean Square)) and four weighted networks (A, C, Lin and allpass). Moreover, the instrument has a measurement range of 30 to130 $\mathrm{dB}$.

SPL was measured in each company before, during and at the end of the work shift. Then, the logarithmic mean of the measured SPLs was computed, which was equivalent to 8 hours exposure to occupational noise (ISO 9612, 1997). Meanwhile, only one type of noise (continuous noise) existed in all companies. Also, according to ITCOH (Iranian Technical Committee of Occupational Health), 8 hours exposure to workplace noise should not exceed $85 \mathrm{dBA}$.

For data analysis the SPSS software and $\mathrm{X}^{2}$ test were used. In principle, the $\mathrm{X}^{2}$ test was used to investigate:

1. An association between exposure to workplace noise, blood pressure and age.

2. A relationship between occupational noise exposure, blood pressure and work experience.

\section{RESULTS}

As shown in Table 1, most of workers in the case and control groups belonged to age group of 30-44y and work experience category of $\geq 4 y$.

Table 1: Frequency distribution of age and work experience of case and control groups.

\begin{tabular}{|c|c|c|c|c|c|}
\hline \multirow{2}{*}{ Group } & \multicolumn{2}{|c|}{ Case } & \multicolumn{2}{c|}{ Control } \\
\cline { 3 - 6 } & Variable & $\mathrm{N}$ & $\%$ & $\mathrm{~N}$ & $\%$ \\
\hline \multirow{3}{*}{ Age } & $\leq 29$ & 26 & 14.9 & 46 & 26.4 \\
\cline { 2 - 6 } & $30-44$ & 116 & 66.3 & 96 & 55.2 \\
\cline { 2 - 6 } & $\geq 45$ & 33 & 18.9 & 32 & 18.4 \\
\cline { 2 - 6 } & Total & 175 & 100 & 174 & 100 \\
\hline \multirow{3}{*}{$\begin{array}{c}\text { Work } \\
\text { experience }\end{array}$} & $\leq 3 \mathrm{y}$ & 20 & 11.42 & 27 & 15.51 \\
\cline { 2 - 6 } & $\geq 4 \mathrm{y}$ & 155 & 88.58 & 147 & 84.49 \\
\cline { 2 - 6 } & Total & 175 & 100 & 174 & 100 \\
\hline
\end{tabular}

Table 2 shows that $68.8 \%$ of the case group and $84.5 \%$ of the control group have a systolic blood pressure of $<130$. Table 2 also shows that $81.7 \%$ of the case group and 
$94.3 \%$ of the control group have a diastolic blood pressure of $<85$. Therefore, based on Tables 3 and 4 it can be stated that most of workers in the case and control groups have normal blood pressure. In other words, $61.7 \%$ of the case group and $81 \%$ of the control group have normal blood pressure.

Table 2. Frequency distribution of blood pressure of case and control groups.

\begin{tabular}{|c|c|c|c|c|c|}
\hline \multirow{2}{*}{ Group } & \multicolumn{2}{c|}{ Case } & \multicolumn{2}{c|}{ Control } \\
\cline { 2 - 6 } Blood pressure & $\mathbf{N}$ & $\%$ & $\mathbf{N}$ & $\%$ \\
\hline \multirow{4}{*}{ Systolic } & $<130$ & 120 & 68.8 & 147 & 84.5 \\
\cline { 2 - 6 } & $130-139$ & 1 & 0.6 & 0 & 0 \\
\cline { 2 - 6 } & $\geq 140$ & 54 & 30.9 & 27 & 15.5 \\
\cline { 2 - 6 } & Total & 175 & 100 & 174 & 100 \\
\hline \multirow{4}{*}{ Diastolic } & $<85$ & 143 & 81.7 & 164 & 94.3 \\
\cline { 2 - 6 } & $85-89$ & 0 & 0 & 0 & 0 \\
\cline { 2 - 6 } & $\geq 90$ & 32 & 18.3 & 10 & 5.7 \\
\cline { 2 - 6 } & Total & 175 & 100 & 174 & 100 \\
\hline
\end{tabular}

Table 3. WHO classification of systolic and diastolic blood pressure (WHO-ISH, 1999).

\begin{tabular}{|l|c|c|}
\hline \multicolumn{1}{|c|}{ CATEGORY } & $\begin{array}{c}\text { SYSTOLIC } \\
\text { (mmHg) }\end{array}$ & $\begin{array}{c}\text { DIASTOLIC } \\
\text { (mmHg) }\end{array}$ \\
\hline Optimal & $<120$ & $<80$ \\
Normal & $<130$ & $<85$ \\
High - Normal & $130-139$ & $85-89$ \\
Grade 1 Hypertension ("mild") & $140-159$ & $90-99$ \\
Subgroup: Borderline & $140-149$ & $90-94$ \\
Grade 2 Hypertension ("moderate") & $160-179$ & $100-109$ \\
Grade 3 Hypertension ("severe") & $\geq 180$ & $\geq 110$ \\
Isolated Systolic Hypertension & $\geq 140$ & $<90$ \\
Subgroup: Borderline & $140-149$ & $<90$ \\
\hline
\end{tabular}


Table 4. Frequency distribution of blood pressure of case and control groups based on WHO guideline (WHO-ISH, 1999).

\begin{tabular}{|c|c|c|c|c|}
\hline Group & \multicolumn{2}{|c|}{ Case } & \multicolumn{2}{c|}{ Control } \\
\cline { 2 - 5 } Blood pressure & $\mathbf{N}$ & $\boldsymbol{\%}$ & $\mathbf{N}$ & $\boldsymbol{\%}$ \\
\hline Normotensive & 108 & 61.7 & 141 & 81 \\
\hline Borderline & 0 & 0 & 0 & 0 \\
\hline Hypertensive & 67 & 38.3 & 33 & 19 \\
\hline Total & 175 & 100 & 174 & 100 \\
\hline
\end{tabular}

The measured noise levels in 12 companies are given in Figure1. As can be seen in the figure, noise levels in most of companies exceeded the NIOSH (1998) standard.

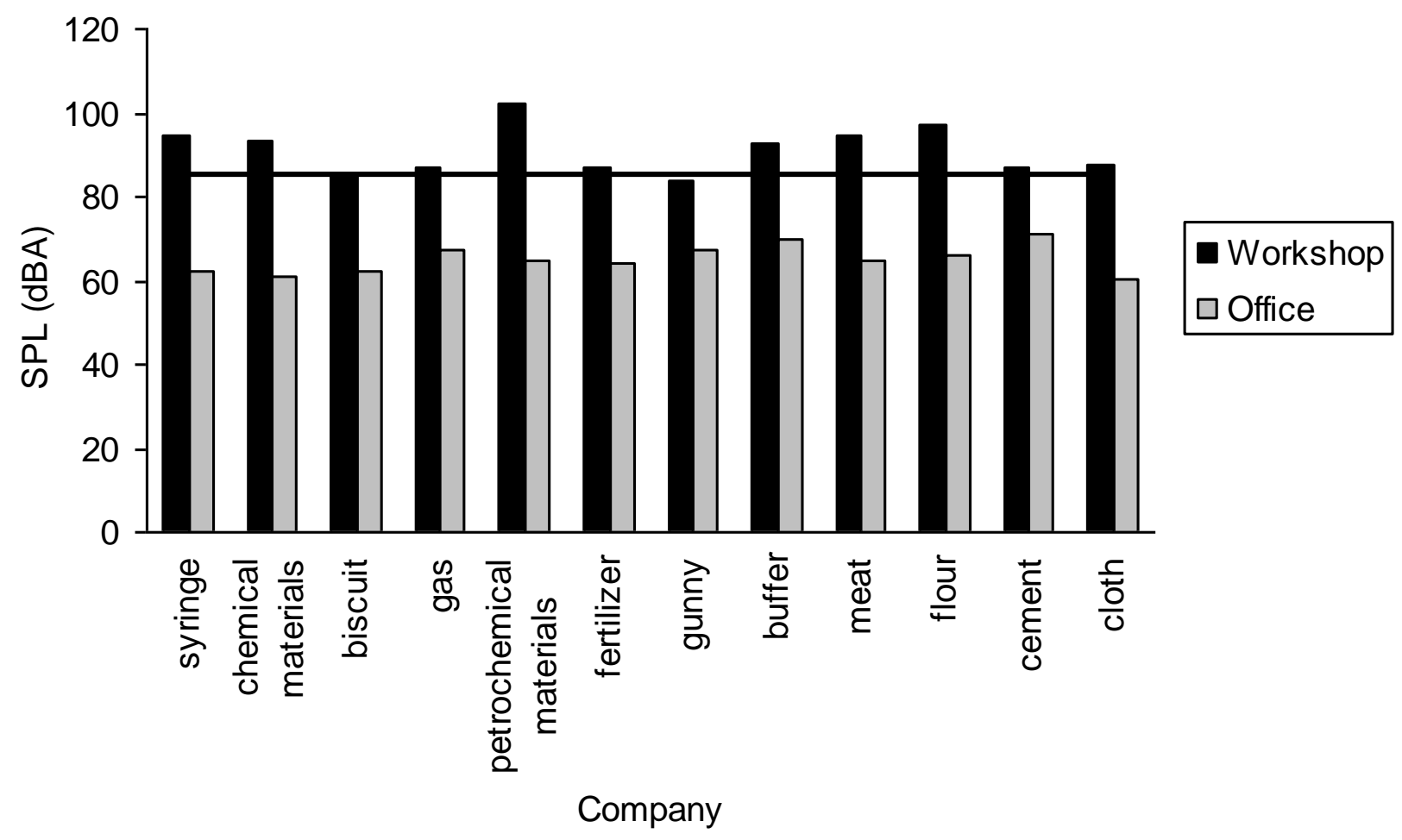

Figure 1. Noise levels in 12 companies in Ilam, Iran.

Frequency distribution of blood pressure of the case group based on SPL and work experience is presented in Table 5. Accordingly, of 42 workers exposed to SPL $\leq 84$ dBA, 27 have normal blood pressure (systolic BP (Blood Pressure) $<130 \&$ diastolic BP <85). Moreover, of 115 workers exposed to 85-99 dBA SPL, 70 have normal blood pressure. Also, among 18 workers exposed to SPL $\geq 100 \mathrm{dBA}, 11$ have normal blood pressure. Furthermore, there is a significant statistical relationship between SPL $\geq 100 \mathrm{dBA}$, blood pressure and work experience of $\geq 4 \mathrm{y}(\mathrm{p}=0.026)$. 
Table 5. Frequency distribution of blood pressure of case group based on SPL and work experience.

\begin{tabular}{|c|c|c|c|c|c|c|c|c|}
\hline \multirow{2}{*}{$\begin{array}{c}\text { SPL } \\
(\text { dBA })\end{array}$} & \multirow{2}{*}{$\begin{array}{c}\text { Work } \\
\text { experience }(y)\end{array}$} & \multicolumn{2}{|c|}{$1-3$} & \multicolumn{2}{|c|}{$\geq 4$} & \multicolumn{2}{|c|}{ Total } & \multirow{2}{*}{$\begin{array}{l}\text { Statistical } \\
\text { relationship }\end{array}$} \\
\hline & & $\mathbf{N}$ & $\%$ & $\mathbf{N}$ & $\%$ & $\mathbf{N}$ & $\%$ & \\
\hline \multirow{4}{*}{ SPL: $\leq 84$} & $\begin{array}{l}\text { Systolic }<130 \\
\text { Diastolic }<85\end{array}$ & 5 & 2.86 & 22 & 12.57 & 27 & 15.43 & \multirow{4}{*}{ not observed } \\
\hline & $\begin{array}{l}\text { Systolic }<130 \\
\text { Diastolic } \geq 90\end{array}$ & 0 & 0 & 3 & 1.72 & 3 & 1.72 & \\
\hline & $\begin{array}{l}\text { Systolic } \geq 140 \\
\text { Diastolic }<85\end{array}$ & 1 & 0.57 & 7 & 4 & 8 & 4.57 & \\
\hline & $\begin{array}{l}\text { Systolic } \geq 140 \\
\text { Diastolic } \geq 90\end{array}$ & 0 & 0 & 4 & 2.28 & 4 & 2.28 & \\
\hline \multirow{5}{*}{$\begin{array}{l}\text { SPL: } 85- \\
\quad 99\end{array}$} & $\begin{array}{l}\text { Systolic }<130 \\
\text { Diastolic }<85\end{array}$ & 8 & 4.57 & 62 & 35.43 & 70 & 40 & \multirow{5}{*}{ not observed } \\
\hline & $\begin{array}{l}\text { Systolic }<130 \\
\text { Diastolic } \geq 90\end{array}$ & 1 & 0.57 & 8 & 4.57 & 9 & 5.14 & \\
\hline & $\begin{array}{c}\text { Systolic 130-139 } \\
\text { Diastolic } \geq 90\end{array}$ & 0 & 0 & 1 & 0.57 & 1 & 0.57 & \\
\hline & $\begin{array}{l}\text { Systolic } \geq 140 \\
\text { Diastolic }<85\end{array}$ & 3 & 1.72 & 19 & 10.86 & 22 & 12.58 & \\
\hline & $\begin{array}{l}\text { Systolic } \geq 140 \\
\text { Diastolic } \geq 90\end{array}$ & 0 & 0 & 13 & 7.43 & 13 & 7.43 & \\
\hline \multirow{4}{*}{ SPL: $\geq 100$} & $\begin{array}{l}\text { Systolic }<130 \\
\text { Diastolic }<85\end{array}$ & 2 & 1.14 & 9 & 5.14 & 11 & 6.28 & \multirow{4}{*}{$\begin{array}{c}X^{2}=11.1 \\
d f=4 \\
p=0.026\end{array}$} \\
\hline & $\begin{array}{l}\text { Systolic } \geq 140 \\
\text { Diastolic }<85\end{array}$ & 0 & 0 & 5 & 2.86 & 5 & 2.86 & \\
\hline & $\begin{array}{l}\text { Systolic } \geq 140 \\
\text { Diastolic } \geq 90\end{array}$ & 0 & 0 & 2 & 1.14 & 2 & 1.14 & \\
\hline & Total & 20 & 11.43 & 155 & 88.57 & 175 & 100 & \\
\hline
\end{tabular}

Table 6 presents frequency distribution of blood pressure of the control group based on SPL and work experience. As can be seen in the table, $81.03 \%$ of workers belonged to work experience categories of $1-3 y$ and $\geq 4 y$, have normal blood pressure.

Frequency distribution of blood pressure of the case group based on SPL and age is given in Table 7. Accordingly, among 42 workers exposed to SPL $\leq 84 \mathrm{dBA}, 27$ have normal blood pressure. Moreover, of 115 workers exposed to 85-99 dBA SPL, 70 have normal blood pressure. In addition, among 18 workers exposed to SPL $\geq 100 \mathrm{dBA}$, 11 have normal blood pressure. Furthermore, there is no significant statistical relationship between SPL, blood pressure and age. 
Table 8 presents frequency distribution of blood pressure of the control group based on SPL and age. As can be seen in the table, $81.04 \%$ of workers belonged to age groups of $\leq 29 \mathrm{y}, 30-44 \mathrm{y}$ and $\geq 45 \mathrm{y}$, have normal blood pressure.

Overall, based on Fig. 1 and Table 5 it can be stated that noise exposure only in petrochemical industry is problematic.

Table 6. Frequency distribution of blood pressure of control group based on SPL and work experience.

\begin{tabular}{|c|c|c|c|c|c|c|c|}
\hline \multirow{4}{*}{$\begin{array}{c}\text { SPL } \\
\text { (dBA) }\end{array}$} & $\begin{array}{c}\text { Work } \\
\text { experience(y) }\end{array}$ & \multicolumn{2}{|c|}{$\mathbf{1 - 3}$} & \multicolumn{2}{|c|}{$\geq \mathbf{4}$} & \multicolumn{2}{c|}{ Total } \\
\cline { 2 - 8 } & $\begin{array}{l}\text { Blood } \\
\text { pressure }\end{array}$ & $\mathbf{N}$ & $\mathbf{\%}$ & $\mathbf{N}$ & $\mathbf{\%}$ & $\mathbf{N}$ & $\%$ \\
\hline \multirow{5}{*}{ SPL: $<75$} & $\begin{array}{l}\text { Systolic }<130 \\
\text { Diastolic }<85\end{array}$ & 25 & 14.36 & 116 & 66.67 & 141 & 81.03 \\
\cline { 2 - 8 } & $\begin{array}{l}\text { Systolic }<130 \\
\text { Diastolic } \geq 90\end{array}$ & 2 & 1.15 & 4 & 2.3 & 6 & 3.45 \\
\cline { 2 - 8 } & $\begin{array}{l}\text { Systolic } \geq 140 \\
\text { Diastolic }<85\end{array}$ & 0 & 0 & 23 & 13.22 & 23 & 13.22 \\
\cline { 2 - 8 } & $\begin{array}{l}\text { Systolic } \geq 140 \\
\text { Diastolic } \geq 90\end{array}$ & 0 & 0 & 4 & 2.3 & 4 & 2.3 \\
\cline { 2 - 9 } & Total & 27 & 15.51 & 147 & 84.49 & 174 & 100 \\
\hline
\end{tabular}


Table 7. Frequency distribution of blood pressure of case group based on SPL and age.

\begin{tabular}{|c|c|c|c|c|c|c|c|c|c|c|}
\hline \multirow{2}{*}{$\begin{array}{c}\text { SPL } \\
(\text { dBA })\end{array}$} & \multirow{2}{*}{$\begin{array}{l}\text { Age } \\
\text { Blood } \\
\text { pressure }\end{array}$} & \multicolumn{2}{|c|}{$\leq \mathbf{2 9}$} & \multicolumn{2}{|c|}{$30-44$} & \multicolumn{2}{|c|}{$\geq 45$} & \multicolumn{2}{|c|}{ Total } & \multirow{2}{*}{$\begin{array}{l}\text { Statistical } \\
\text { relationship }\end{array}$} \\
\hline & & $\mathbf{N}$ & $\%$ & $\mathbf{N}$ & $\%$ & $\mathbf{N}$ & $\%$ & $\mathbf{N}$ & $\%$ & \\
\hline \multirow{4}{*}{ SPL: $\leq 84$} & $\begin{array}{l}\text { Systolic }<130 \\
\text { Diastolic }<85\end{array}$ & 7 & 4 & 16 & 9.14 & 4 & 2.28 & 27 & 15.61 & \multirow{4}{*}{ not observed } \\
\hline & $\begin{array}{l}\text { Systolic }<130 \\
\text { Diastolic } \geq 90\end{array}$ & 0 & 0 & 3 & 1.71 & 0 & 0 & 3 & 1.71 & \\
\hline & $\begin{array}{l}\text { Systolic } \geq 140 \\
\text { Diastolic }<85\end{array}$ & 0 & 0 & 7 & 4 & 1 & 0.57 & 8 & 4.57 & \\
\hline & $\begin{array}{l}\text { Systolic } \geq 140 \\
\text { Diastolic } \geq 90\end{array}$ & 0 & 0 & 2 & 1.14 & 2 & 1.14 & 4 & 2.28 & \\
\hline \multirow{5}{*}{$\begin{array}{c}\text { SPL: } 85- \\
99\end{array}$} & $\begin{array}{l}\text { Systolic }<130 \\
\text { Diastolic }<85\end{array}$ & 10 & 5.71 & 49 & 28 & 11 & 6.28 & 70 & 39.99 & \multirow{5}{*}{ not observed } \\
\hline & $\begin{array}{l}\text { Systolic }<130 \\
\text { Diastolic } \geq 90\end{array}$ & 4 & 2.28 & 5 & 2.85 & 0 & 0 & 9 & 5.13 & \\
\hline & $\begin{array}{c}\text { Systolic } 130- \\
139 \\
\text { Diastolic } \geq 90\end{array}$ & 0 & 0 & 0 & 0 & 1 & 0.57 & 1 & 0.57 & \\
\hline & $\begin{array}{l}\text { Systolic } \geq 140 \\
\text { Diastolic }<85\end{array}$ & 2 & 1.14 & 15 & 8.57 & 5 & 2.85 & 22 & 12.56 & \\
\hline & $\begin{array}{l}\text { Systolic } \geq 140 \\
\text { Diastolic } \geq 90\end{array}$ & 0 & 0 & 8 & 4.57 & 5 & 2.85 & 13 & 7.42 & \\
\hline \multirow{4}{*}{ SPL: $\geq 100$} & $\begin{array}{l}\text { Systolic }<130 \\
\text { Diastolic }<85\end{array}$ & 2 & 1.14 & 7 & 4 & 2 & 1.14 & 11 & 6.28 & \multirow{4}{*}{$\begin{array}{c}X^{2}=13 \\
d f=7 \\
p=0.06\end{array}$} \\
\hline & $\begin{array}{l}\text { Systolic } \geq 140 \\
\text { Diastolic } 1<85\end{array}$ & 0 & 0 & 4 & 2.28 & 1 & 0.57 & 5 & 2.85 & \\
\hline & $\begin{array}{l}\text { Systolic } \geq 140 \\
\text { Diastolic } \geq 90\end{array}$ & 0 & 0 & 1 & 0.57 & 1 & 0.57 & 2 & 1.14 & \\
\hline & Total & 25 & 14.27 & 117 & 66.82 & 33 & 18.82 & 175 & 100 & \\
\hline
\end{tabular}


Table 8. Frequency distribution of blood pressure of control group based on SPL and age.

\begin{tabular}{|c|c|c|c|c|c|c|c|c|c|}
\hline \multirow{2}{*}{$\begin{array}{c}\text { SPL } \\
\text { (dBA) }\end{array}$} & \multirow{2}{*}{$\begin{array}{l}\text { Age } \\
\text { plood } \\
\text { pressure }\end{array}$} & \multicolumn{2}{|c|}{$\leq 29$} & \multicolumn{2}{|c|}{$30-44$} & \multicolumn{2}{|c|}{$\geq 45$} & \multicolumn{2}{|c|}{ Total } \\
\hline & & $\mathbf{N}$ & $\%$ & $\mathbf{N}$ & $\%$ & $\mathbf{N}$ & $\%$ & $\mathbf{N}$ & $\%$ \\
\hline \multirow{5}{*}{ SPL: $<75$} & $\begin{array}{l}\text { Systolic }<130 \\
\text { Diastolic }<85\end{array}$ & 42 & 24.13 & 80 & 45.97 & 19 & 10.91 & 141 & 81.04 \\
\hline & $\begin{array}{l}\text { Systolic }<130 \\
\text { Diastolic } \geq 90\end{array}$ & 1 & 0.57 & 4 & 2.3 & 1 & 0.57 & 6 & 3.44 \\
\hline & $\begin{array}{l}\text { Systolic } \geq 140 \\
\text { Diastolic }<85\end{array}$ & 2 & 1.14 & 8 & 4.59 & 9 & 5.17 & 19 & 10.92 \\
\hline & $\begin{array}{l}\text { Systolic } \geq 140 \\
\text { Diastolic } \geq 90\end{array}$ & 1 & 0.57 & 4 & 2.3 & 3 & 1.72 & 8 & 4.59 \\
\hline & Total & 46 & 26.44 & 96 & 55.17 & 32 & 18.39 & 174 & 100 \\
\hline
\end{tabular}

\section{DISCUSSION}

The results of the present paper indicated a link between exposure to noise level of $\geq 100 \mathrm{dBA}$ and hypertension in petrochemical industry. In contrast, de Souza et al. (2015) reported an association between exposure to noise levels of 75-85 dBA and $\geq 85 \mathrm{dBA}$ and hypertension in a petrochemical factory. In addition, Chang et al. (2013) investigated blood pressure status of workers of an aircraft manufacturing plant. They concluded that prolonged exposure to noise level of $\geq 85 \mathrm{dBA}$ may cause a rise in systolic and diastolic blood pressure. Moreover, Yousefi Rizi and Dehghan (2012) found no relationship between exposure to noise above $85 \mathrm{dBA}$ and blood pleasure in metal industry. Furthermore, Kalantary et al (2015) studied the effect of noise level on blood pressure among auto parts workers. They found that occupational exposure to noise level of 85-108 dBA cannot cause hypertension.

In addition, the findings of the present work indicated a relationship between exposure to workplace noise, hypertension and work experience of $\geq 4 y$. Moreover, the results of the present study revealed no relationship between occupational noise exposure, blood pressure and age. In contrast, Tiwai et al (2003) studied an association between exposure to noise and hypertension in a textile plant. They found that the prevalence of hypertension was significantly higher among persons belonged to age group of 35 years or more and work experience category of 10 years and more. Furthermore, Rapisarda et al. (2015) investigated a relationship between exposure to noise and blood pressure among workers of a battery recycling plant. Age and work experience of subjects were considered by them. Their results showed that blood pressure did not correlate with occupational noise exposure. 
Overall, based on the results of the present survey it can be stated that in any companies where noise level is equal to or exceeds $100 \mathrm{dBA}$, investigation of blood pressure status of workers is highly recommended. But whereas occupational noise can cause different physiological and psychological disorders in workers, it is better to keep workplace noise level below the NIOSH recommended exposure limit, $85 \mathrm{dBA}$. Meanwhile, if workplace noise reduction is impossible the use of hearing protection devices is recommended.

It must be noted that whereas hypertension is reported to be associated with gender and work shift (de Souza et al., 2015; Pimenta et al., 2012), the results of the present paper cannot necessarily be extrapolated to female workers and night shift workers. In addition, because an impulsive noise is much more harmful than a continuous noise (Khopkar, 2004), the findings of the present work cannot necessarily be extrapolated to workers exposed to impulsive noise too.

It must also be noted that whereas chronic exposure to noise is associated with increased risk of hypertension (Lafferty, 2013), it is better to perform a longitudinal study (Tavakoli, 2012) in order to investigate a relationship between occupational noise exposure and blood pressure because by considering this type of research it is possible to investigate the topic among a group of participants over a period of time (e.g. several years).

\section{CONCLUSIONS}

An association between noise exposure and blood pressure among male workers from 12 companies was investigated in this paper. The results indicated a significant statistical relationship between exposure to occupational noise level of $\geq 100 \mathrm{dBA}$, hypertension and work experience of $\geq 4 \mathrm{y}$. Therefore to study a relationship between exposure to workplace noise and blood pressure, work experience must be taken into consideration.

\section{ACKNOWLEDGMENTS}

The authors wish to appreciate Tehran University of Medical Sciences and Ilam University of Medical Sciences for financial support of this study (contract No.3738-2703-85).

\section{ETHICAL OVERSIGHT AND CONFLICT OF INTEREST}

This study was approved by the local ethical committee and written informed consents were obtained from the participants. Meanwhile, the authors have no conflict of interest with regard to the research included in this paper. 


\section{REFERENCES}

Agarwal, S.K. 2009. Noise pollution. APH Publishing Corporation, New Delhi, India. $180 \mathrm{pp}$.

Autenrieth, D. 2011. Occupational exposures to noise resulting from the workplace use of personal media players. MSc Thesis, Colorado State University.

Aziz, S. and Aziz, Z. 2015. Understanding high blood pressure. Chapter 3, Sheldon Press, London, U.K. 130 pp.

Bugliarello, G., Alexandre, A., Barnes, J. and Wakstein, C. 1976. The impact of noise pollution: A socio-technological introduction. Pergamon Press, London, U.K. $486 \mathrm{pp}$.

Chang, T.Y., Hwang, B.F., Liu, C.S., Chen, R.Y., Wang, V.S., Bao, B.Y. and Lai, J.S. 2013. Occupational noise exposure and incident hypertension in men: A prospective cohort study. American Journal of Epidemiology, 177(8): 818-825.

Chen, T.H., Fan, C.F. and Wang, M.J. 2015. The effects of cleanroom noise intensity and frequency on physiological measures and subjective responses. Work, 51(4): 771-780.

de Souza, T.C.F., Périssé, A.R.S. and Moura, M. 2015. Noise exposure and hypertension: investigation of a silent relationship. BMC Public Health, 15: 328.

Ernst, A. 2003. Comparison of qualitative and quantitative research, Seminar Paper, GRIN Verlag, University of St. Gallen, Swizerland, 7 pp.

Fogari, R., Zoppi, A., Vanasia, A., Marasi, G. and Villa, G. 1994. Occupational noise exposure and blood pressure. Journal of Hypertension, 12(4): 475-480.

Green, R.D. 2014. Occupational noise exposures of college town restaurant employees. MSc Thesis, University of Lowa.

Ismaila, S.O. and Odusote, A. 2014. Noise exposure as a factor in the increase of blood pressure of workers in a sack manufacturing industry. Beni-Suef University Journal of Basic and Applied Sciences, 3(2):116-121.

ISO 9612. 1997. Acoustics-Guidelines for the measurement and assessment of exposure to noise in a working environment.

Jain, R., Urban, L., Balbach, H. and Webb, M.D. 2012. Handbook of environmental engineering assessment: Strategy, planning, and management. Elsevier, Oxford, U.K. 784 pp.

Kalantary, S., Dehghani, A., Yekaninejad, M.S., Omidi, L. and Rahimzadeh, M. 2015. The effects of occupational noise on blood pressure and heart rate of workers in an automotive parts industry. ARYA Atheroscler, 11(4): 215-219.

Khopkar, S.M. 2004. Environmental pollution monitoring and control. New Age International, New Delhi, India. 494 pp.

Krueger, G.P., Brewster, R.M., Dick, V.R., Inderbitzen, R.E. and Staplin, L. 2007. Health and wellness programs for commercial drivers. Transportation Research Board, Washington, D.C, U.S.A. 80 pp.

Lafferty, J.S. 2013. Potential health effects of noise exposure. Madison, WI: Public Health Madison \& Dane County; 06/13/13-Noise Exposure. 
Levy, B.S., Wagner, G.R., Rest, K.M. and Weeks, J.L. 2005. Preventing occupational disease and injury. American Public Health Association; Washington, D.C, U.S.A. 590 pp.

Loue, S. and Sajatovic, M. 2012. Encyclopedia of immigrant health. Springer, New York, U.S.A. 1516 pp.

Nassiri, P. and Abbasi, A.M. 2009. The interaction of noise pollution and blood pressure in a textile company in Ilam, Iran. International Journal of Occupational Hygiene, 1(1): 14-19.

NIOSH. 1998. Criteria for a recommended standard: occupational noise exposure. Revised criteria 1998. Cincinnati, OH, National Institute for Occupational Safety and Health.

OSHB-Occupational Safety and Health Branch. 2008. Work and hypertension, Labor Department, Helsinki, Finland, 14 pp.

Pimenta, A.M., Kac, G., Souza, R.R.C., Ferreira, L.M.B.A. and Silqueira, S.M.F. 2012. Night-shift work and cardiovascular risk among employees of a public university. Revista da Associação Médica Brasileira, 58(2):168-177.

Rapisarda, V., Ledda, C., Ferrante, M., Fiore, M., Cocuzza, S., Bracci, M. and Fenga, C. 2016. Blood pressure and occupational exposure to noise and lead (Pb)-A crosssectional study. Toxicology and Industrial Health, 32(10): 1729-1736.

Sancini, A., Caciari, T., Rosati, M.V., Samperi, I., Iannattone, G., Massimi, R., Loreti, B., Scala, B., Sacco, C., Tomei, F. and Tomei, G. 2014. Can noise cause high blood pressure? Occupational risk in paper industry. Clin Ter, 165(4):e304-311.

Stokholm, Z.A, Bonde, J.P., Christensen, K.L., Hansen, A.M. and Kolstad, H.A. 2013. Occupational noise exposure and the risk of hypertension. Epidemiology, 24(1):135-142.

Tavakoli, H. 2012. A dictionary of research methodology and statistics in applied linguistics. Rahnama Press, Tehran, Iran. 766 pp.

Tiwai, R.R., Pathak, M.C., Zodpey, S.P. and Babar, V.Y. 2003. Hypertension among cotton textile workers. Indian Journal of Public Health, 47(1): 34-36.

van Kempen, E.E., Kruize, H., Boshuizen, H.C., Ameling, C.B., Staatsen, B.A. and de Hollander, A.E. 2002. The association between noise exposure and blood pressure and ischemic heart disease: A meta-analysis. Environmental Health Perspectives, 110(3): 307-317.

Vincoli, J.W. 2000. Lewis' dictionary of occupational and environmental safety and health. CRC Press, Florida, U.S.A. 1104 pp.

WHO-ISH. 1999. Hypertension guidelines committee, World Health OrganizationInternational Society of Hypertension Guidelines for the Management of Hypertension. Journal of Hypertension, 17(2): 151-183.

Yousefi Rizi, H.A. and Dehghan, H. 2012. Effects of occupational noise exposure on changes in blood pressure of workers. ARYA Atherosclerosis Journal, 8 (Special Issue in National Hypertension Treatment): S183-S186.

Zamanian, Z., Rostami, R., Hasanzadeh, J. and Hashemi, H. 2013. Investigation of the effect of occupational noise exposure on blood pressure and heart rate of steel industry workers. Journal of Environmental and Public Health, 1-3. 